\title{
Author Correction: Puma genomes from North and South America provide insights into the genomic consequences of inbreeding
}

\author{
Nedda F. Saremi (D), Megan A. Supple, Ashley Byrne, James A. Cahill (1), Luiz Lehmann Coutinho, Love Dalén, \\ Henrique V. Figueiró, Warren E. Johnson (1), Heather J. Milne, Stephen J. O'Brien, Brendan O'Connell, \\ David P. Onorato (1), Seth P.D. Riley, Jeff A. Sikich, Daniel R. Stahler, Priscilla Marqui Schmidt Villela, \\ Christopher Vollmers, Robert K. Wayne, Eduardo Eizirik (D), Russell B. Corbett-Detig, Richard E. Green, \\ Christopher C. Wilmers \& Beth Shapiro
}

Correction to: Nature Communications https://doi.org/10.1038/s41467-019-12741-1, published online 18 October 2019.

The original version of this Article contained several errors. In Figure 3a, both axes were incorrectly labelled as "PC2". The correct $\mathrm{x}$ axis label is "PC1". The present affiliation of Warren E Johnson with the Walter Reed Biosystematics Unit, Smithsonian Institution, was inadvertently omitted. The following statement was also omitted from the Acknowledgements: "Portions of this manuscript were prepared while W.E.J held a National Research Council Research Associateship Award at the Walter Reed Army Institute of Research and the published material reflects the views of the authors and should not be construed to represent those of the Department of the Army or the Department of Defense." The initials "W.J" in the Author Contributions statement should have been listed as "W.E.J". These errors have now been corrected in both the PDF and HTML versions of the Article.

Published online: 21 November 2019

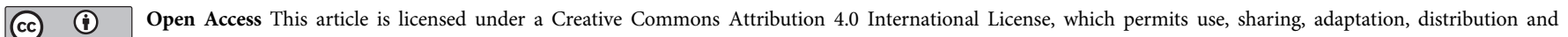
reproduction in any medium or format, as long as you give appropriate credit to the original author(s) and the source, provide a link to the Creative Commons license, and indicate if changes were made. The images or other third party material in this article are included in the article's Creative Commons license, unless indicated otherwise in a credit line to the material. If material is not included in the article's Creative Commons license and your intended use is not permitted by statutory regulation or exceeds the permitted use, you will need to obtain permission directly from the copyright holder. To view a copy of this license, visit http://creativecommons.org/licenses/by/4.0/.
}

(C) The Author(s) 2019 